\title{
Asynchronous Hatching and Extended Parental Care in Aegla schmitti (Decapoda, Anomura)
}

\author{
Carolina de Lima Adam ${ }^{1}$, Murilo Marochi ${ }^{1}$, Mariana Lacerda ${ }^{1}$, Andre Trevisan $^{2}$, Setuko \\ Masunari ${ }^{1}$. \\ ${ }^{1}$ Universidade Federal do Paraná - Setor de Ciências Biologicas - Zoologia, Curitiba, Brasil; ${ }^{2}$ Universidade Alto \\ Vale do Rio Peixe, Caçador, Santa Catarina, Brasil.
}

\begin{abstract}
The aim of this study was to describe the behavior of newly-hatched juveniles and maternal care in Aegla schmitti. The experiment was conducted using seven ovigerous females with eggs at different stages of embryonic development and 12 eggs that had been placed in a separate aquarium. We observed asynchronous hatching in all females, with a mean of 66 hatched juveniles per female. The females also exhibited extended maternal care, allowing the juveniles to remain inside their abdominal chamber or on other parts of their body in the first few days after hatching. The juveniles that hatched in a separate aquarium fed on the remaining eggs, despite food being available. The incubation period and number of hatched eggs are highly variable between species with direct development, with no clear pattern being evident. However, asynchrony in hatching time is apparently common among freshwater anomurans, most likely due to the environmental conditions in which they live. Parental care is an important trait for crustaceans that live in osmotically unfavorable environments, such as freshwater, increasing the survival rate of juveniles.
\end{abstract}

Key words: Crustacean behavior, maternal care, hatching period, Aeglidae.

\footnotetext{
*Author for correspondence: caroladam27@hotmail.com
} 


\section{INTRODUCTION}

According to Trivers (1972), the term "parental care" covers any parental feature that improves the adaptive value of the spawn, sometimes at great energetic cost to the parents ${ }^{1,2}$. Parental care is highly variable between species, comprising both nonbehavioral and behavioral traits ${ }^{3}$. For example, among invertebrates, it can include the production of trophic eggs, the protection of eggs and/or larvae inside or outside the progenitor's body, the active care of recently hatched eggs and, occasionally, the provision of food to juveniles ${ }^{4}$. The continuous care of offspring following hatching is known as extended parental care ${ }^{5}$, and Thiel (2003) estimated that $46 \%$ of Decapoda species exhibit this form of parental care, including the genus $\mathrm{Aegla}^{6}$. The extended care of offspring probably evolved multiple times in freshwater taxa ${ }^{7}$ and is a useful adaptation for freshwater conditions, where the maintenance of an internal osmotic balance is more costly than in a marine environment ${ }^{8}$. Thus, parental care can minimize the high mortality rate during the initial life stages ${ }^{7,9,10}$.

Family Aeglidae Dana, 1952 consists of freshwater anomurans with a marine origin ${ }^{1}{ }^{1}$. Currently, this family has only one extant genus, Aegla Leach, 1820, which comprises 78 species $^{12}$ that are endemic to the southern region of South America ${ }^{13}$. These species inhabit different freshwater environments, such as rivers, streams, lakes, and caves, and are the only anomurans that complete their entire life cycle in continental waters ${ }^{14}$. The aeglids exhibit epimorphic development, with the hatched juveniles being morphologically similar to the adults ${ }^{15}$.

Although many species of aeglids have a narrow distribution ${ }^{16}$, Aegla schmitti Hobbs III, 1978 has a particularly broad distribution, occurring in the Ribeira de Iguape and Litorânea river basins and in the east of the Iguaçu river basin, Paraná, Brazil ${ }^{14}$. This species has a highly variable morphology, which may be related to reproductive isolation, geological events, and environmental differences between populations ${ }^{17,18}$. According to Teodosio and Masunari (2009) and Chiquetto-Machado et al. (2016), A. schmitti has two reproductive cycles during its life, with the most intense period of egg incubation occurring during winter and hatching mostly occurring in early spring ${ }^{19,20}$. Little is currently known about juvenile behavior and parental care in Aeglidae, with only one study having focused exclusively on parental care ${ }^{21}$.

In addition to affecting offspring survival and growth, extended parental care can also have implications for recruitment and juvenile dispersal ${ }^{7}$, and so an understanding of parental care can clarify how brooding behavior influences population density. Therefore, given the highly variable morphology in this species, a better understanding of its parental care may help demonstrate how juveniles disperse, and how this affects meta-population dynamics and gene flow. Consequently, the aim of this study was to describe the behavior of newly-hatched juveniles and maternal care in A. schmitti under laboratory conditions.

\section{MATERIAL AND METHODS}

\section{Sampling of $A$. schmitti}

We used hand nets to collect ovigerous females of A. schmitti $(n=7)$ from the Capivari River, Ribeira do Iguape river basin, municipality of Bocaiúva do Sul, Paraná, Brazil $\left(25^{\circ} 10^{\prime} 12.7^{\prime \prime} \mathrm{S}, 4^{\circ} 6^{\prime} 35.9^{\prime \prime} \mathrm{W}\right)$ on August 8, 2014. We placed the aeglids in boxes containing water from the collection site and transported them to the Crustacean Ecology Laboratory, in the Federal University of Paraná, where we measured the cephalothorax length (CL) of each female, from the tip of the rostrum to the posterior end of the carapace, using a digital caliper with a precision of 0.01 
$\mathrm{mm}$. We also categorized the embryonic stage of development of the egg mass as early, intermediate, or late based on the color of the eggs, the development of the embryos' eyes and the volume of the yolk mass ${ }^{22}$.

\section{Laboratory procedures}

The adult females were placed in individual aquaria $(20 \times 20 \times 20 \mathrm{~cm})$ that were filled with water from the sampling site, and had constant aeration, a controlled temperature $\left(18 \pm 1{ }^{\circ} \mathrm{C}\right.$ ), and a photoperiod of 12:12 (dark/light) hours. They were fed fish filets every 48 hours. Each experimental aquarium also contained rocks from the collection site to provide shelter.

The females were checked every day for hatched juveniles and egg loss, and to observe the stage of embryonic development (Fig. 1A). Egg loss was quantified by counting the number of eggs dispersed in the aquaria each day.

To assess the viability of eggs outside the female's abdominal chamber, we also kept 12 eggs of $A$. schmitti at different stages of development in a separate aquarium under the same experimental conditions.

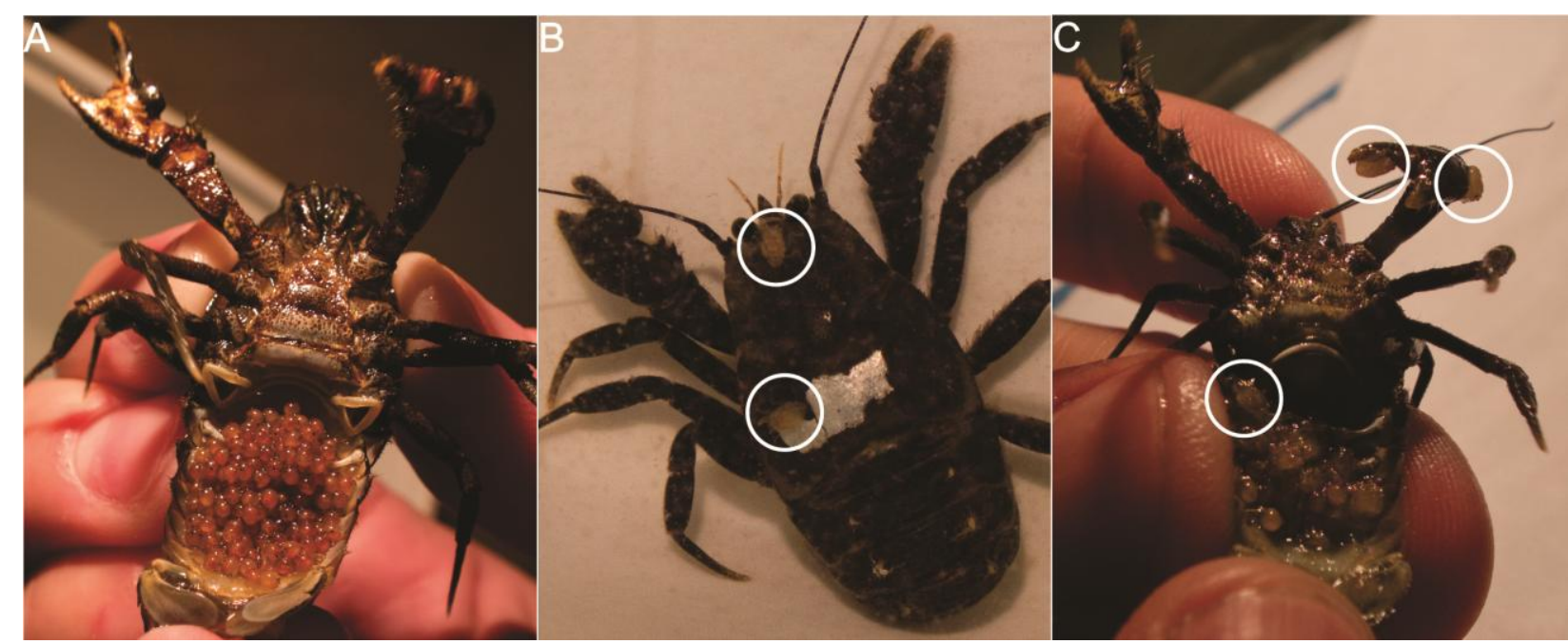

Figure 1. Ovigerous female of Aegla schmitti (A), juveniles on the dorsal surface of cephalothorax (B) and juveniles occupying the female abdominal chamber (C).

\section{RESULTS}

The carapace length of the ovigerous females ranged between $21.03 \mathrm{~mm}$ and 29.92 $\mathrm{mm}$, and the average number of hatched juveniles was $66 \pm 30$ per female.

Aegla schmitti exhibit asynchronous egg hatching in all analyzed females. We observed a high peak in hatching over the 6 days that followed the first hatched egg for each female (Fig. 2), following which there was a high mortality of juveniles until the end of the experiment. Only 4 of the 12 eggs that were maintained separately from the female hatched, and these fed on the remaining eggs, despite food being available ad libitum in the aquarium.

Juveniles were found in the abdominal chamber, on the carapace, and/or on the chelae of the females (Fig. $1 \mathrm{~B}, \mathrm{C}$ ). We also observed the females moving the egg mass. 


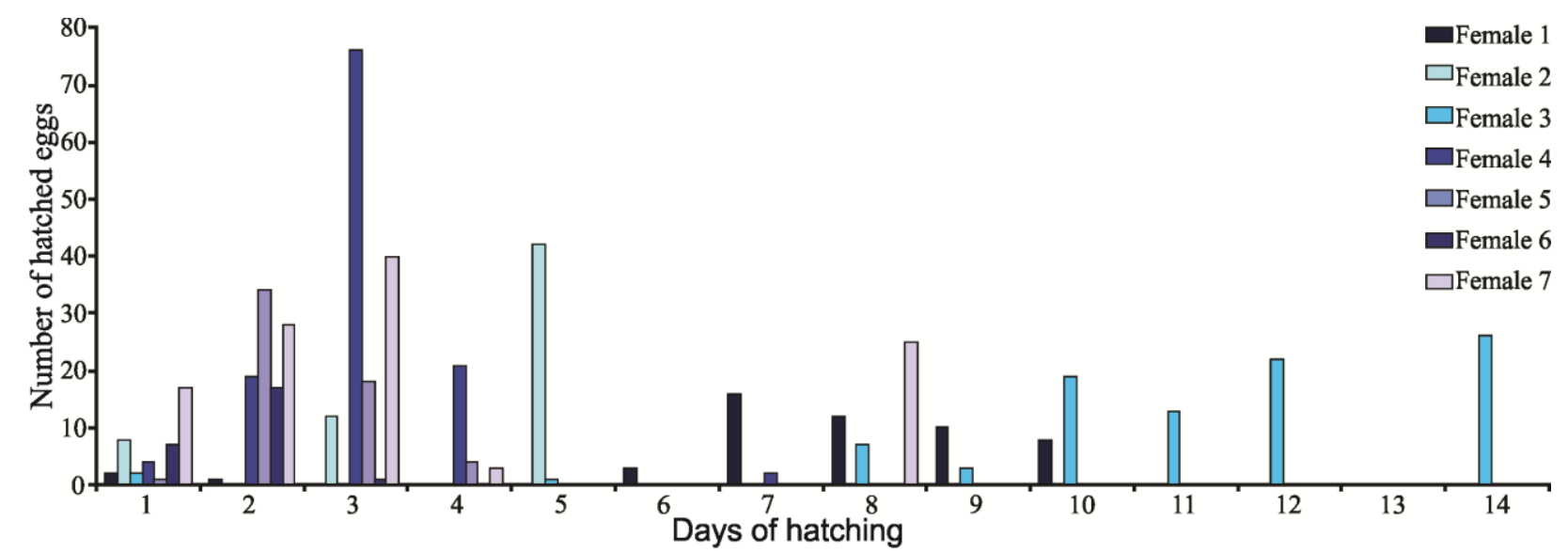

Figure 2. Number of hatched eggs for each female during the experiment.

\section{DISCUSSION}

In the present study, the mean number of hatched juveniles per female was 66, with asynchronous hatching occurring in all individuals. We also observed maternal care in all analyzed individuals, with juveniles being found on the body and chelae of the females during the first few days after hatching. Furthermore, juveniles were found to prey on unhatched eggs when isolated from their mother.

The observed variation in juvenile hatching may be explained by three different hypotheses. The first hypothesis is differential maternal investment. According to Benton et al. (2005), the amount of nutrients allocated by a mother to her offspring varies according to food availability and her age $\mathrm{e}^{23}$. The authors argued that maternal investment can affect hatching time, juvenile performance, and even population dynamics. Within same brood, eggs can contain different amounts of nutrients, which may indicate an unequal investment from the female to her offspring ${ }^{24}$. Pochelon et al. (2011) reported within-brood variability in the fatty acid profiles of the eggs of Nephrops norvegicus Linnaeus, 1758, and suggested differential maternal investment as one of the possible causes for this variation ${ }^{25}$. Oxygen provision is also linked to maternal brooding behavior. According to Fernandez et al. (2000) and Baeza and Fernandez (2002), oxygen availability in the egg mass can be influenced by certain behaviors exhibit by brooding females ${ }^{26,27}$. For example, in the brachyuran crabs Cancer setosus Molina, 1782 and Homalaspis plana MilneEdwards, 1834, Fernandez et al. (2003) found variation in oxygen availability in the embryonic chamber, with the inner embryos exhibiting lower levels of oxygen in both species ${ }^{28}$. This scenario led to hatching asynchrony because the embryos that were located in the periphery of the embryonic chamber, with higher levels of oxygen, consumed the yolk more rapidly and consequently hatched earlier.

The second hypothesis is related to differential catabolism between individuals. Variation in catabolism, combined with nutrient availability, can lead to variation in juvenile hatching, because some embryos are able to consume the yolk and develop more quickly than others, resulting in them hatching earlier. Pochelon et al. (2011) also suggested that this may be a possible cause for the observed variability in fatty acid profiles in the egg brood of $N$. norvegicus ${ }^{25}$.

The third hypothesis is related to environmental conditions. In a natural environment, where food is often an unpredictable resource, hatching asynchrony may be beneficial. Stevens (2006) proposed that hatching at different times may guarantee that at least some of the offspring will hatch concomitantly with food availability ${ }^{29}$. However, this hypothesis is unlikely to explain the observed variation 
Juvenile behavior and parental care in Aeglidae

in this species because aeglids are omnivorous generalists and food is constantly available in freshwater sub-tropical environments, particularly in rivers with riparian vegetation $^{30,31}$.

The mean number of hatched juveniles per female $A$. schmitti in the present study $(66 \pm 30)$ was lower than has previously been estimated for the closely related $A$. uruguayana $(142.87 \pm 28.49)^{21}$. This difference may be related to intrinsic variation in the species' biology, due to the number of eggs lost prior to capture, the nutritional/physiological conditions and sizes of the females, the number of consecutive broods, food availability and quality, and other biotic and abiotic factors that are commonly attributed to reproductive variability in Decapoda ${ }^{32}$.

Parental care is a trait that has evolved multiple times during evolution ${ }^{33}$. According to Thiel (2003), there are 130 species of crustaceans with extended parental care, and in 19 of these the juveniles remain on the female's body during the early stage of development, which is considered the most primitive form of brood care behavior ${ }^{5,33}$. This behavior was evident in A. schmitti, with juveniles being found inside the abdominal chamber after hatching, and then remaining on the female's cephalothorax and chelae for the next 16 days. A similar behavior has been observed in other aeglids. For example, in A. castro, parental care lasted for 15 days, during which time the juveniles remained on the female's carapace and pleopods ${ }^{34}$, while in A. uruguayana, this period was considerably shorter, with juveniles remaining strictly inside the female's abdomen on the first day, and then exploring the rest of her body over the following 3-4 days ${ }^{21}$. Among other anomurans, parental care has been described in hermit crabs of the genus Calcinus $^{35}$, which produce very small numbers of large eggs and allow the juveniles to stay inside the host's gastropod shell for the entire larval stage. According to Thiel (1999), the duration of parental care depends on many factors, such as resource availability at a given time or the risk of predation ${ }^{9}$. However, species that carry their offspring on their bodies rarely extend this period past the first stage of development, because it would be too energetically costly to carry larger juveniles ${ }^{5}$.

Most marine Decapoda are r-strategists, producing thousands to millions of small eggs per clutch, and their development is marked by many larval stages ${ }^{7,36}$. By contrast, freshwater Decapoda usually have fewer and larger eggs ${ }^{37}$. A smaller brood size, abbreviated development, and extended parental care are probably favorable traits in physiologically stressful environments, particularly during the period when these organisms transitioned from the ocean to conquer freshwater and land ${ }^{7,33}$. Some species of freshwater decapods have even developed specialized structures, such as terminal hooks on their pereiopods, to help them attach to the female's body $^{38,39}$, although there is no report of such appendages in Aeglidae. Extended parental care causes the juveniles to stay close to the mother, leading to local recruitment, which may be one of the causes of reduced gene flow ${ }^{5}$. Consequently, this may explain the highly endemic distribution of many aeglid species, and may be one of the factors influencing the morphological variation between different populations of A. schmitti ${ }^{18}$.

Our results provide new evidence for extended parental care in aeglids and demonstrate asynchrony in the hatching period. These findings have important implications for our understanding of the reproductive strategies and adaptations that were required to successfully invade freshwater environments. Future studies that comprise the entire incubation phase following fertilization will clarify the exact length of the development period and give more precise information on the causes of this hatching asynchrony.

\section{ACKNOWLEDGEMENT}


We are thankful to Coordenação de Aperfeiçoamento de Pessoal de Nível Superior (CAPES) and the Conselho Nacional de Desenvolvimento Científico e Tecnológico (CNPq) for the master and doctoral scholarships granted to the first and second authors, respectively. To the Postgraduate Program in Zoology, Federal University of Paraná for providing the facilities for this study. We are thankful to Dr. Luis Amilton Foerster for the article revision. The authors would also like to thank Enago (www.enago.com.br) for the English language review.

\section{REFERENCES}

1- Trivers RL. Parental investment and sexual selection. First Edition. Chicago: Aldine Publishing Company; 1972.

2- Clutton-Brock TH. The evolution of parental care. First Edition. New Jersey: Princeton University Press; 1991.

3- Smiseth PT, Kölliker M, Royle NJ. What is parental care? In: Kölliker M, editor. The evolution of parental care. First Edition, Oxford: Oxford University Press; 2012.

4- Trumbo ST. Patterns of parental care in invertebrates. In: Kölliker M, editor. The evolution of parental care. First Edition, Oxford: Oxford University Press; 2012

5- Thiel M. Extended parental care behavior in crustaceans - A comparative overview. In: Klein JCV, Schram FR, editors. The biodiversity crisis and crustacea. First Edition. Rotterdam: A.A. Balkema Publishers; 2000.

6- Thiel M. Extended parental care in crustaceans - an update. Rev. Chil. Hist. Nat. 2003; 76: 205-218.

7- Vogt G. Abbreviation of larval development and extension of brood care as key features of the evolution of freshwater Decapoda. Biol. Rev. 2012.

8- Powers LW, Bliss DE. Terrestrial adaptations. In: Vernberg FJ, Vernberg WB, editors. The biology of Crustacea: Environmental Adaptations, New York: Academic Press; 1983.

9- Thiel M. Duration of extended parental care in marine amphipods. J. Crustacean Biol. 1999; 19(1): 60-71.

10- Vogt G. Life span, early life stage protection, mortality, and senescence in freshwater Decapoda. In: Yeo DCJ, Cumberlidge N, Klaus S, editors. Advances in freshwater decapod systematics and biology. First Edition. Leiden: Koninklijke; 2014.

11- Pérez-Losada M, Bond-Buckup G, Jara CG, Crandall KA. Molecular systematics and biogeography of the southern south American freshwater "crabs" Aegla (Decapoda: Anomura: Aeglidae) using multiple heuristic tree search approaches. Syst. Biol. 2004; 53(5): 767-780.

12- Santos S, Bond-Buckup G, Buckup L, Bartholomei-Santos ML, Pérez-Losada M, Jara CG, et al. Three new species of Aeglidae (Aegla Leach, 1820) from Paraná State, Brazil. J. Crustacean Biol. 2015; 35(6): 839-849.

13- Bond-Buckup G, Jara CG, Pérez-Losada M, Buckup L, Crandall KA. Global diversity of crabs (Aeglidae: Anomura: Decapoda) in freshwater. Hydrobiologia. 2008; 595(1): 267273.

14- Bond-Buckup G. Família Aeglidae. In: Melo GAS, editors. Manual de identificação dos Crustacea Decapoda de água doce do Brasil. First Edition. São Paulo: Edições Loyola; 2003.

15- Bond-Buckup G, Bueno AAP, Keunecke KA. Primeiro estágio juvenile de Aegla prado Schmitt (Crustacea, Decapoda, Anomura, Aegladae). Rev. Brasil. Zoo. 1996; 13(4): 10491061.

16- Bond-Buckup G, Buckup LA. Família Aeglidae (Crustacea, Decapoda, Anomura). Arq. Zool. 1994; 32(4): 159-346.

17- Trevisan A, Masunari S. Geographical distribution of Aegla schmitti Hobbs III, 1979 (Decapoda Anomura Aeglidae) and morphometric variations in male populations from Paraná State, Brazil. Nauplius. 2010; 18(1): 45-55.

18- Trevisan A, Marochi MZ, Costa M, Santos S, Masunari S. Effects of the evolution of the Serra do Mar mountains on the shape of the geographically isolated populations of Aegla schmitti Hobbs III, 1979 (Decapoda: Anomura). Acta Zool. 2016; 97(1): 34-41. 
Juvenile behavior and parental care in Aeglidae

19- Teodósio EAO, Masunari S. Estrutura populacional de Aegla schmitti (Crustacea: Anomura: Aeglidae) nos reservatórios dos Mananciais da Serra, Piraquara, Paraná, Brasil. Zoologia. 2009; 26(1).

20- Chiquetto-Machado PI, Vieira LC, Shimizu RM, Bueno SL. Life cycle of the freshwater anomuran Aegla schmitti Hobbs, 1978 (Decapoda: Anomura: Aeglidae) from southeastern Brazil. J. Crustacean Biol. 2016; 36(1): 39-45.

21- Greco LSL, Viau V, Lavolpe M, Bond-Buckup G. Rodriguez EM. Juvenile hatching and maternal care in Aegla uruguayana (Anomura, Aeglidae). J. Crustacean Biol. 2004; 24(2): 309-313.

22- Bueno SLS, Schimizu RM. Reproductive biology and functional maturity in females of Aegla franca (Decapoda: Anomura: Aeglidae). J. Crustacean Biol. 2008; 28(4): 652-662.

23- Benton TG, Plaistow SJ, Beckerman AP, Lapsley CT, Littlejohns S. Changes in maternal investment in eggs can affect population dynamics. P. Roy. Soc. Lond. B: Bio. 2005; 272(1570): 1351-1356.

24- Clarke A. Egg size and egg composition in polar shrimps (Caridea; Decapoda). J. Exp. Mar. Biol. Ecol. 1993; 168(2): 189-203.

25- Pochelon PN, Da Silva TL, Reis A, Dos Santos A, Queiroga H, Calado R. Interindividual and within-brood variability in the fatty acid profiles of Norway lobster, Nephrops norvegicus (L.) embryos. Mar. Biol. 2011; 158(12): 2825-2833.

26- Fernández M, Bock C. Pörtner HO. The cost of being a caring mother: the ignored factor in the reproduction of marine invertebrates. Ecol. Lett. 2000; 3(6): 487-494.

27- Baeza JA, Fernández M. Active brood care in Cancer setosus (Crustacea: Decapoda): the relationship between female behaviour, embryo oxygen consumption and the cost of brooding. Funct. Ecol. 2002; 16(2): 241-251.

28- Fernández M, Ruiz-Tagle N, Cifuentes S, Pörtner HO, Arntz W. Oxygen-dependent asynchrony of embryonic development in embryo masses of brachyuran crabs. Mar. Biol. 2003; 142(3): 559-565.

29- Stevens BG. Timing and duration of larval hatching for blue king crab Paralithodes platypus Brandt, 1850 held in the laboratory. J. Crustacean Biol. 2006; 26(4): 495-502.

30- Bueno AAP, Bond-Buckup G. Natural diet of Aegla platensis Schmitt and Aegla ligulata Bond-Buckup \& Buckup (Crustacea, Decapoda, Aeglidae) from Brazil. Acta Limnol. Bras. 2004; 16(2): 115-127.

31- Cogo GB, Santos S. The role of aeglids in shredding organic matter in neotropical streams. J. Crustacean Biol. 2013; 33(4): 519-526.

32- Hines AH. Allometric constraints and variables of reproductive effort in brachyuran crabs. Mar. Biol. 1982; 69(3): 309-320.

33- Anger K. The conquest of freshwater and land by marine crabs: adaptations in life-history patterns and larval bioenergetics. J. Exp. Mar. Biol. Ecol. 1995; 193: 119-145.

34- Swiech-Ayoub BP, Masunari S. Biologia reprodutiva de Aegla castro Schmitt (Crustacea, Anomura, Aeglidae) no Buraco do Padre, Ponta Grossa, Paraná, Brasil. Rev. Bras. Zool. 2001; 18(3): 1019-1030.

35- Calado R, Nogueira N, Santos A. Extended parental care in a hermit crab of the genus Calcinus (Anomura: Diogenidae). J. Mar. Biol. Assoc.U.K. 2006; 86: 121-123.

36- Fratini S, Schubart CD, Ragionieri L. Population genetics in the rocky shore crab Pachygrapsus marmoratus from the western Mediterranean and eastern Atlantic: complementary results from mtDNA and microsatellites at different geographic scales. Crustac. Issues. 2011; 9(18): 191 - 213.

37- Pennak RW. The freshwater invertebrate fauna: problems and solutions for evolutionary success. Am. Zool. 1985; 25: 671-687.

38- Scholtz G, Kawai T. Aspects of embryonic and postembryonic development of the Japanese freshwater crayfish Cambaroides japonicas (Crustacea, Decapoda) including a hypothesis on the evolution of maternal care in the Astacida. Acta Zool. - Stockholm. 2012; 83: 203-212.

39- Vogt G, Tolley L. Brood care in freshwater crayfish and relationship with the offspring's sensory deficiencies. J. Morphol. 2004; 262: 566-582. 
Received: February 03, 2016; Accepted: July 14, 2016 